Departement für Pferde

der Vetsuisse-Fakultät Universität Zürich

Direktor: Prof. Dr. Anton Fürst, Dipl. ECVS, FVH

Saddle pressure distributions of three saddles used in Icelandic horses and their effects on ground reaction forces, limb movements and rider positions at walk and tölt

\author{
Inaugural-Dissertation \\ zur Erlangung der Doktorwürde der \\ Vetsuisse-Fakultät Universität Zürich
}

vorgelegt von

Lea Claudia Ramseier

Tierärztin

von Trub (BE)

genehmigt auf Antrag von

PD Dr. Michael A. Weishaupt, Referent

Zürich 2012 
Inhalt

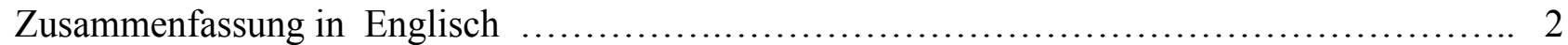

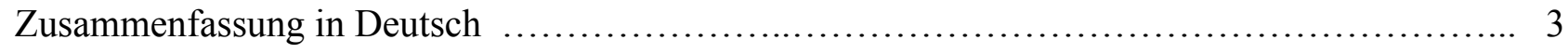

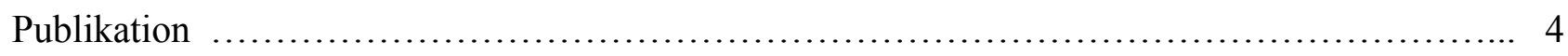

Danksagung

Lebenslauf 


\section{Saddle pressure distributions of three saddles used in Icelandic horses and their effects on ground reaction forces, limb movements and rider positions at walk and tölt}

Ramseier, Lea Claudia, 2012

Vetsuisse-Fakultät Universität Zürich, Departement für Pferde, Abteilung Sportmedizin gschmid@vetclinics.uzh.ch

Icelandic horse riding practices aim to place the rider further caudally on the horse's back than in English riding, claiming that a weight shift toward the hindquarters improves the quality of the tölt (e.g., giving the shoulder more freedom to move). This study compared saddle pressure patterns and the effects on limb kinetics and kinematics of three saddles: an Icelandic saddle ( $\mathrm{S}_{\text {Icell }}$, lowest point of seat in the caudal part of the saddle), a treeless saddle cushion ( $\mathrm{S}_{\text {Cush }}$ ) and a dressage-style saddle $\left(\mathrm{S}_{\text {Dres }}\right)$. Twelve Icelandic horses were ridden with $\mathrm{S}_{\text {Icel, }}, \mathrm{S}_{\text {Cush }}$ and $\mathrm{S}_{\text {Dres }}$ on an instrumented treadmill at walk and tölt. Saddle pressure, limb forces and kinematics were recorded simultaneously. With $\mathrm{S}_{\text {Cush, }}$ pressure was highest under the front part of the saddle, whereas, the saddles with trees had more pressure under the caudal area. The saddles had no influence on the motion patterns of the limbs. The slight weight shift to the rear with $\mathrm{S}_{\text {Cush }}$ and $\mathrm{S}_{\text {Icel }}$ may be explained by the more caudal position of the rider relative to the horse's back.

Keywords: GRF; Icelandic horse; Kinematics; Saddle pressure; Tölt 
Druckverteilung von drei im Islandpferdesport eingesetzten Sätteln und ihr Einfluss auf Bodenreaktionskräfte, Gliedmassenbewegungen und die Position des Reiters in Schritt und Tölt

Ramseier, Lea Claudia, 2012

Vetsuisse-Fakultät Universität Zürich, Departement für Pferde, Abteilung Sportmedizin gschmid@vetclinics.uzh.ch

Im Vergleich zur englischen Reitweise wird beim Islandpferdereiten angestrebt den Reiter weiter hinten auf dem Pferderücken zu positionieren. Hierdurch soll eine Gewichtsverlagerung auf die Nachhand erreicht und so die Qualität des Tölts verbessert werden (z.B. aufgrund vermehrter Schulterfreiheit). In der vorliegenden Studie wurden drei im Islandpferdesport eingesetzte Sättel bezüglich der Druckverteilung und ihres Einflusses auf die Belastung und Bewegungen der Gliedmassen verglichen: ein Islandpferdesattel $\left(\mathrm{S}_{\text {Icel }}\right)$ mit dem tiefsten Punkt im hinteren Bereich des Sattels, ein baumloses Sattelkissen $\left(\mathrm{S}_{\mathrm{Cush}}\right)$ und ein Dressursattel ( $\left.\mathrm{S}_{\text {Dres }}\right)$. Zwölf Islandpferde wurden mit diesen drei Sätteln im Schritt und Tölt auf einem instrumentierten Laufband geritten. Die Messung von Druckverteilung, kinetischen und kinematischen Parametern erfolgte synchron. Die höchsten Druckwerte wurden beim Sattelkissen im vorderen Bereich des Sattels gemessen, wohingegen die Sättel mit Sattelbaum mehr Druck im hinteren Bereich ausübten. Die Sättel hatten keinen Einfluss auf die Gliedmassenbewegung der Pferde. Die mit $S_{\text {Icel }}$ und $S_{\text {Cush }}$ erzielte leichte Gewichtsverlagerung auf die Nachhand wird durch die kaudalere Position des Reiters in Relation zum Pferderücken verursacht sein.

Schlüsselwörter: Bodenreaktionskräfte; Islandpferd; Kinematik; Satteldruck; Tölt 


\title{
Saddle pressure distributions of three saddles used for Icelandic horses and their effects on ground reaction forces, limb movements and rider positions at walk and tölt
}

\author{
Lea C. Ramseier, Nina M. Waldern, Thomas Wiestner, Katja Geser-von Peinen*, Michael A. Weishaupt \\ Equine Department, Vetsuisse Faculty, University of Zurich, CH-8057 Zurich, Switzerland
}

\section{A R T I C L E I N F O}

\section{Keywords:}

Ground reaction force

Icelandic horse

Kinematics

Saddle pressure

Tölt

\begin{abstract}
A B S T R A C T
Icelandic horse riding practices aim to place the rider further caudally on the horse's back than in English riding, claiming that a weight shift toward the hindquarters improves the quality of the tölt (e.g. giving the shoulder more freedom to move). This study compared saddle pressure patterns and the effects on limb kinetics and kinematics of three saddles: an Icelandic saddle $\left(S_{\text {Icel }}\right.$, lowest point of seat in the hind part of the saddle), a treeless saddle cushion $\left(S_{\text {Cush }}\right)$ and a dressage-style saddle $\left(S_{\text {Dres }}\right)$. Twelve Icelandic horses were ridden with $S_{\text {Icel, }} S_{\text {Cush }}$ and $S_{\text {Dres }}$ on an instrumented treadmill at walk and tölt. Saddle pressure, limb forces and kinematics were recorded simultaneously. With $S_{\text {Cush }}$, pressure was highest under the front part of the saddle, whereas the saddles with trees had more pressure under the hind area. The saddles had no influence on the motion patterns of the limbs. The slight weight shift to the rear with $S_{\text {Cush }}$ and $S_{\text {Icel }}$ may be explained by the more caudal position of the rider relative to the horse's back.
\end{abstract}

(C) 2013 Elsevier Ltd. All rights reserved.

\section{Introduction}

Icelandic horses are known for their special gaits, particularly the four-beat tölt, which can be ridden from walking up to cantering speeds. To assist the horse at the tölt, it is stated that the rider needs to induce a slight weight shift toward the horse's hindquarters (Feldmann, 1986). This can be achieved by the rider having a more caudal position in relation to the horse's back (Feldmann, 1986) and/or by elevation of the head and neck. The aforementioned approach aims to 'free-up the shoulder,' resulting in increased movement of the shoulder and, consequently, the forelimb, a desirable effect in Icelandic horse competitions. With respect to these demands, special saddling and riding techniques have been developed empirically in Iceland and have been adopted world-wide.

There are different ways to position the rider more caudally with respect to the horse's centre of mass (COM), either by placing the rider in the rear part of the saddle or, more effectively, by positioning the whole saddle further caudally on the horse's back. Traditionally, large saddles with padded bars (Trachtensättel) extending into the lumbar region with a wide seat and the deepest point of the saddle far back were used to ride long distances comfortably. Nowadays, Icelandic saddles are shorter, but still have the deepest point of the seat caudal to the centre of the saddle. Treeless

\footnotetext{
* Corresponding author. Tel.: +41 446358881.

E-mail address: kvonpeinen@vetclinics.uzh.ch (K. Geser-von Peinen).
}

saddles are also widely used, based on the idea that they fit every horse and allow the rider to adjust the seat position according to the need to support the gait.

The common Icelandic riding and saddling practices are partly contradictory to the basic principles applied in English riding that aim to place the rider close to the horse's COM and the deepest point of the seat approximately at the centre of the saddle; this makes it easier for the rider to balance and move in harmony with the horse (Harman, 2004). Moreover, it is known that the caudal part of the back is particularly sensitive to load (Nyikos et al., 2005). Nevertheless, the effects of these Icelandic saddling and riding practices on back and orthopaedic health, as well as the range of motion of the back and forelimbs, have not yet been studied. In this context, it is worth noting that Icelandic horses are rarely presented clinically due to back pain, although their rather stoic nature might mask possible discomfort.

As a consequence of biomechanical studies of other breeds, the traditional saddling and riding methods considered normal in Icelandic horses are being judged with increasing scepticism (Haag and Schwörer-Haag, 2003). A new type of saddle for Icelandic horses has recently been developed, which has a design similar to that of English dressage saddles. These saddles are to be positioned according to the recommendations for English saddles used in non-gaited horse breeds, as described by Harman (2004).

The aim of this study was to compare the effects on pressure distribution under the saddle and effects on limb forces and kinematics of three saddles: two saddles with trees of differing design 
and with differently localised deepest point of the seat, as well as a treeless saddle. We hypothesised that a saddle with a more caudally positioned deepest point of the seat would load the back more caudally, but would not influence the forelimb-hind limb balance and movements of the horse.

\section{Materials and methods}

Experimental design

Twelve Icelandic horses ( 4 mares, 5 stallions and 3 geldings; mean \pm standard deviation: age $11.5 \pm 3$ years; height at the withers $1.37 \pm 0.03 \mathrm{~m}$; bodyweight $354 \pm 25 \mathrm{~kg}$ ) were each ridden with three different saddles on a treadmill (Mustang 2200 , Graber AG) at walk $(1.3 \mathrm{~m} / \mathrm{s})$ and tölt $(3.4 \mathrm{~m} / \mathrm{s})$. Horses were free of lameness and pain or dysfunction of the back. All horses were accustomed to the treadmil and were ridden by one of two experienced riders of 65.2 and $74.5 \mathrm{~kg}$ bodyweight; each horse was ridden in all trials by the same rider. Accuracy of gait and posture of the horse were assessed by an experienced judge of Icelandic horses. The experimental protocol was approved by the Animal Health and Welfare Commission of the Canton of Zürich, Switzerland (approval number 206/2010).

Three saddle types (Fig. 1) placed in the standard position (Harman, 2004) were investigated in random order on the same day: (1) a dressage-style saddle ( $S_{\text {Dres }}$ Pleasure II, ChampionRider; weight $8.3 \mathrm{~kg}$ ) with its deepest point in the middle of the saddle; $(2)$ a traditional Icelandic saddle ( $S_{\text {Icel; }} ; Z$-Sattel, TopReiter; $7.5 \mathrm{~kg}$ ), with the deepest point of the seat slightly toward the cantle; and (3) a treeless saddle cushion $\left(S_{\text {Cush }}\right.$; Sattelkissen, TopReiter; $7.3 \mathrm{~kg}$ ). The $S_{\text {Icel }}$ and $S_{\text {Cush }}$ were only available in one size. The $S_{\text {Dres }}$ was available with four different head plate sizes; based on manual and visual evaluation (Harman, 2004) and saddle pressure measurements, the most suitable saddle was chosen for each horse.

\section{Data acquisition}

Kinematic, kinetic and saddle pressure data were measured simultaneously. Vertical ground reaction force (GRF) and temporal and spatial variables of each limb were measured with a treadmill-integrated force measuring system (TiF Weishaupt et al., 2002). Kinematic data were obtained by tracking spherical reflective markers (diameter $19 \mathrm{~mm}$ ) placed over anatomical landmarks on both sides of the horse, rider and saddle mat with nine infrared cameras (Oqus 600, Qualysis). Qualisys Track Manager software (Qualysis) was used to control the cameras and to calculate the kinematic $x y z$-data. The left-handed coordinate system was aligned with the treadmill, the $x$-axis pointing in direction of the horse's head, the $y$-axis pointing toward its right and the $z$-axis upward.

Saddle pressure was measured with a Pliance-X System (Novel) using a Nove MSA600 pressure sensitive mat placed symmetrically on the horse's back, leaving a small gap along the spine. Zero base line was set before saddling and tightening the girth. Calibration of the pressure-sensitive mat was performed each day prior to data collection. Recordings lasted $15 \mathrm{~s}$, which amounted to $12-14$ strides at walk and 24-26 strides at tölt. Frame rates of $480 \mathrm{~Hz}$ (TiF and Qualysis) and $60 \mathrm{~Hz}$ (Pliance-X) were used.

\section{Data analysis}

The following temporal, spatial and force variables were determined from the force curves and limb positional data of the TiF-system: stride duration (SD), stance duration relative to $S D(S t D)$, ipsilateral step duration relative to $S D\left(S_{p t p D}\right)$, stance length (StL), overreach distance (OR), vertical limb impulse (Iz) and peak vertical $\mathrm{GRF}\left(\mathrm{Fz}_{\text {peak }}\right)$. The percentage of total vertical impulse carried by both forelimbs ( $\left.\mathrm{I}_{\mathrm{fore}}\right)$ was used to assess the horse's impulse balance between forequarters and hindquarters. Limb contact times were converted into stride-standardised times (\%SD) and force and impulse values were standardised to the combined mass of horse, rider and saddle ( $\mathrm{N} / \mathrm{kg}$ and $\mathrm{Ns} / \mathrm{kg}$, respectively). For each variable, the values of the multiple strides in a record were averaged.

Time series of kinematic and saddle pressure data and discrete limb contact times from TiF were imported into MatLab (MathWorks) for further analysis. Based on the stride-cycle times of the left forelimb, time series were split into strides. Data for each stride-cycle were time-standardised to 101 points (0-100\% stride duration) and all strides in a recording were averaged. All further analyses were based on this standardised averaged stride. Corresponding variables of the contralateral limbs were pooled and reported as forelimb and hind limb values.

The following kinematic variables were determined (markers involved are given in brackets): (1) horse: head height (wing of the atlas), forelimb/hind limb protraction and retraction angle (rotation of a marker on the lateral hoof wall at the level of the coffin joint around the calculated midpoint between the left and right shoulder joints or tuber coxae), forearm angle (rotation of the carpus around the elbow) and shoulder rotation around the $x$ - and $z$-axis (both shoulder joints); and (2) rider: rider position relative to horse's back (rider sacrum - horse L5) and rider back angle (rotation of rider C7 around rider sacrum). For each variable, stride mean (mean), range of motion (ROM) and extremes (maximum values) were calculated in three dimensions. Only selected variables are shown in the results; linear dimensions are specified accordingly (e.g. $z$-mean, $x$-ROM).

Of the saddle pressure data, the maximally loaded area under each saddle was determined automatically by only including those sensors that had a pressure $>2 \mathrm{kPa}$ during at least $1 \%$ of SD for at least one of the two gaits. This procedure defined the total area within which the pressure data were processed. Additionally, the total loaded area was mathematically subdivided into transverse thirds $\left(\mathrm{TD}_{\mathrm{front}}\right.$, $\mathrm{TD}_{\text {mid }}, \mathrm{TD}_{\text {hind }}$ ) of equal length. If the division did not result in an integer number of sensor rows, the pressures at the borders of the thirds were proportionally assigned to the respective thirds. For each third and each point in time of the standardised stride, the loaded area $(A)$, force $(F)$ and averaged pressure $(P)$ were calculated. Subsequently, the respective stride-mean variables $\left(A_{\text {mean }}, P_{\text {mean }}\right.$; mean value during the entire stride) and $F_{\text {mean }}$ (percentage of total force acting on a certain third) were derived. Additionally, the maximal averaged pressure $\left(P_{\max }\right)$ of each third and its time of occurrence within the stride were determined. Finally, a maximum pressure picture (MPP) was calculated that showed the peak pressure $\left(P_{\text {peak }}\right)$ occurring for each sensor during the stride. Rider stability was quantified by the longitudinal and lateral ROM of the centre of pressure (COP). By means of markers placed on the caudal end of the saddle mat, the position of the COP (COP position) and the most caudal loaded sensor row (caudal edge loaded area) were related to the horse's L5. The length of the loaded area represented the longitudinal extent of the loaded sensors for each trial.

\section{Statistical methods}

Statistical analysis was performed with SigmaStat 3.5 for both gaits separately. Differences in saddle pressure data between the saddles and among the sector thirds were tested with two-way analysis of variance (ANOVA) for repeated measures (RM); kinetic and kinematic variables were compared for the saddles with one-way RM ANOVA. Normality of data was tested (Kolmogorov-Smirnov distance) and monitored by normal probability plots prior to analysis. Post hoc multiple comparisons were made using the Holm-Sidak procedure. The level of significance was set at $P<0.05$. Descriptive statistics were calculated with Excel (Microsoft).
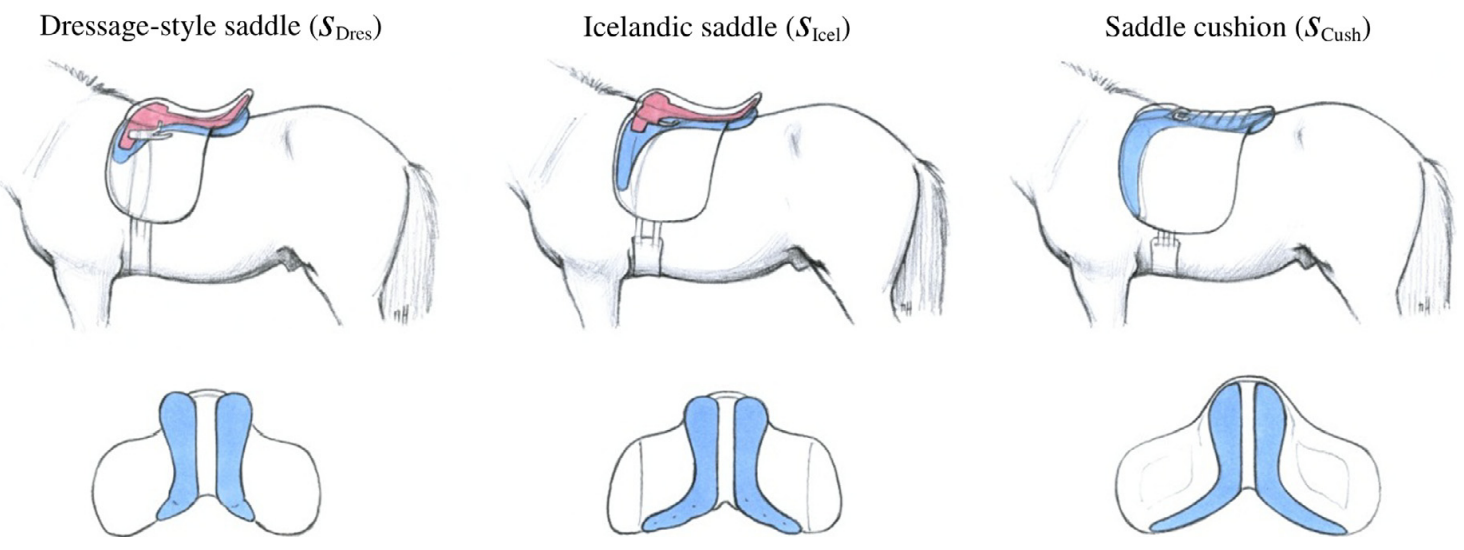

Fig. 1. Diagrams of the tree and panel configurations of the three saddles used in the study. Red, head plate and tree; blue, panels. $S_{\text {Dres: }}$ wooden spring tree, wool cushions, conventional three-strap girth (Edwards, 1963). $S_{\text {Icel }}$ : flexible synthetic tree, latex cushions, two-strap girth with anterior billet attached at the head plate. $S_{\text {Cush: }}$ treeless, foam cushions, two billets attached at the sweat flap. 


\section{Results}

Group mean values of the stride mean variables $A_{\text {mean }}, F_{\text {mean }}$ $P_{\text {mean }}$ and $P_{\text {max }}$, together with $P_{\text {peak }}$, are listed in Table 1 . Kinetic and kinematic variables are listed for walk in Table 2 and tölt in Table 3. Unless otherwise stated, all differences reported hereafter are significant.

\section{Pressure distribution within each saddle}

The number of sensors loaded across the transverse direction of the pressure mat varied between $\mathrm{TD}_{\text {front }}, \mathrm{TD}_{\text {mid }}$ and $\mathrm{TD}_{\text {hind }}$, resulting in differences in total loaded areas among the longitudinal divisions. For all saddles, the largest fraction of the total loaded area $\left(A_{\text {mean }}\right)$ was concentrated on $\mathrm{TD}_{\text {front }}(39-43 \%)$; at walk $\mathrm{TD}_{\text {hind }}$ was greater than $\mathrm{TD}_{\text {mid, }}$, whereas at tölt the caudal two thirds had similar areas.

A similar pattern of load distribution $\left(F_{\text {mean }}\right)$ was seen with all saddles. At both gaits, $\mathrm{TD}_{\text {front }}$ was most loaded, with $38-47 \%$ of the total rider and saddle weight. At walk, the saddles with trees had lower loads in $\mathrm{TD}_{\text {mid }}$ than $\mathrm{TD}_{\text {hind }}$ (bridging phenomenon). At tölt, the remaining load was evenly distributed between $\mathrm{TD}_{\text {mid }}$ and $\mathrm{TD}_{\text {hind }}$ in all saddles.

Comparing the longitudinal pressure patterns revealed distinct differences between $\mathrm{TD}_{\text {front }}, \mathrm{TD}_{\text {mid }}$ and $\mathrm{TD}_{\text {hind }}$ for all saddles. At walk, $P_{\text {mean }}$ for both saddles with trees was highest in $\mathrm{TD}_{\text {hind }}$, whereas in $S_{\text {Cush }}$ it was highest in $\mathrm{TD}_{\text {front }}$. At tölt, $P_{\text {mean }}$ was evenly distributed across all thirds in $S_{\text {Icel }}$, increased from front to caudal in $S_{\text {Dres}}$, with a significant difference only between $\mathrm{TD}_{\text {front }}$ and $\mathrm{TD}_{\text {hind, }}$, and decreased from cranial to caudal in $S_{\text {Cush }}$. The $P_{\max }$ showed similar characteristics. Localisations of peak pressures are illustrated in Fig. 2.

\section{Comparison between saddles}

The $S_{\text {Dres }}$ was the shortest saddle with its total contact area ( $A_{\text {mean }}$ ) being 4.4-6.7\% less than that of both other saddles. The $S_{\text {Cush }}$ was the longest saddle, with the caudal edge of the loaded area extending the farthest back into the lumbar region (Tables 2 and 3).

In terms of force distribution $\left(F_{\text {mean }}\right), S_{\text {Cush }}$ was most loaded in $\mathrm{TD}_{\text {front }}$ and least loaded in $\mathrm{TD}_{\text {mid }}$ (not significantly different from $S_{\text {Dres }}$ at walk) and $\mathrm{TD}_{\text {hind }}$ at both gaits. Comparing the saddles with trees, $S_{\text {Icel }}$ had lower values in $\mathrm{TD}_{\text {hind }}$ at both gaits, but was more loaded in $\mathrm{TD}_{\text {front }}$ at tölt.

Regarding $P_{\text {mean }}, S_{\text {Cush }}$ had the highest values in $\mathrm{TD}_{\text {front }}$ at walk; at tölt, saddles did not differ. The $P_{\text {mean }}$ was lowest in $S_{\text {Cush }}$ at both gaits in both $\mathrm{TD}_{\text {mid }}$ and $\mathrm{TD}_{\text {hind }}$. The $S_{\text {Dres }}$ had the highest $\mathrm{TD}_{\text {hind }}$ values.

\section{Rider position and stability}

Independent of the gait, rider position was more caudal on the horse's back with $S_{\text {Icel }}$ (walk $-12 \mathrm{~mm}$, tölt $-15 \mathrm{~mm}$ ) and $S_{\text {Cush }}$ (walk $-26 \mathrm{~mm}$, tölt $-30 \mathrm{~mm}$ ) than with $S_{\text {Dres. }}$ The COP position did not differ between the saddles with trees; however, in accord

Table 1

Group means ( \pm standard deviations) of loaded area $\left(A_{\text {mean }}\right)$, percentage of mean total force $\left(F_{\text {mean }}\right)$, mean pressure $\left(P_{\text {mean }}\right)$, maximal pressure $\left(P_{\text {max }}\right)$ and peak pressure $\left(P_{\text {peak }}\right)$ of three different saddles ( $S_{\text {Dres, }}$, dressage-style saddle, $S_{\text {Icel, }}$, Icelandic saddle and $S_{\text {Cush }}$, treeless saddle cushion) at walk $(1.33 \pm 0.01 \mathrm{~m} / \mathrm{s})$ and tölt $(3.43 \pm 0.03 \mathrm{~m} / \mathrm{s})$.

\begin{tabular}{|c|c|c|c|c|c|c|}
\hline Variable & Gait & Saddle & $\mathrm{TD}_{\text {front }}$ & $\mathrm{TD}_{\text {mid }}$ & $\mathrm{TD}_{\text {hind }}$ & Total value \\
\hline \multirow[t]{2}{*}{$A_{\text {mean }}\left(\mathrm{cm}^{2}\right)$} & Walk & $\begin{array}{l}S_{\text {Dres }} \\
S_{\text {Icel }} \\
S_{\text {Cush }}\end{array}$ & $\begin{array}{l}437 \pm 37^{a \diamond} \\
465 \pm 42^{b \diamond} \\
488 \pm 28^{c \diamond}\end{array}$ & $\begin{array}{l}315 \pm 21^{\mathrm{a} \#} \\
340 \pm 17^{\mathrm{b} \#} \\
324 \pm 22^{\mathrm{ab} \#}\end{array}$ & $\begin{array}{l}375 \pm 19^{\mathrm{a} \dagger} \\
371 \pm 21^{\mathrm{a} \dagger} \\
356 \pm 20^{\mathrm{a} \dagger}\end{array}$ & $\begin{array}{l}1127 \pm 45^{\mathrm{a}} \\
1175 \pm 48^{\mathrm{b}} \\
1168 \pm 36^{\mathrm{b}}\end{array}$ \\
\hline & Tölt & $\begin{array}{l}S_{\text {Dres }} \\
S_{\text {Icel }} \\
S_{\text {Cush }}\end{array}$ & $\begin{array}{l}472 \pm 39^{\mathrm{a} \diamond} \\
515 \pm 40^{\mathrm{b} \diamond} \\
520 \pm 32^{\mathrm{b} \diamond}\end{array}$ & $\begin{array}{l}319 \pm 25^{\mathrm{a} \#} \\
345 \pm 17^{\mathrm{b \#}} \\
330 \pm 22^{\mathrm{ab \#}}\end{array}$ & $\begin{array}{l}336 \pm 31^{a \#} \\
335 \pm 33^{a \#} \\
352 \pm 30^{a \#}\end{array}$ & $\begin{array}{l}1127 \pm 49^{\mathrm{a}} \\
1195 \pm 62^{\mathrm{b}} \\
1202 \pm 51^{\mathrm{b}}\end{array}$ \\
\hline \multirow[t]{2}{*}{$F_{\text {mean }}(\%)$} & Walk & $\begin{array}{l}S_{\text {Dres }} \\
S_{\text {Icel }} \\
S_{\text {Cush }}\end{array}$ & $\begin{array}{l}38.1 \pm 2.0^{\mathrm{a} \diamond} \\
38.6 \pm 3.4^{\mathrm{a} \diamond} \\
45.8 \pm 3.1^{\mathrm{b} \diamond}\end{array}$ & $\begin{array}{l}27.0 \pm 2.0^{\mathrm{ab \#}} \\
28.3 \pm 2.7^{\mathrm{a} \#} \\
25.8 \pm 1.9^{\mathrm{b} \#}\end{array}$ & $\begin{array}{l}34.9 \pm 2.1^{\mathrm{a} \dagger} \\
33.1 \pm 3.2^{\mathrm{b} \dagger} \\
28.4 \pm 2.8^{\mathrm{c} \#}\end{array}$ & \\
\hline & Tölt & $\begin{array}{l}S_{\text {Dres }} \\
S_{\text {Icel }} \\
S_{\text {Cush }}\end{array}$ & $\begin{array}{l}39.9 \pm 3.2^{\mathrm{a} \diamond} \\
41.9 \pm 3.0^{\mathrm{b} \diamond} \\
46.8 \pm 2.6^{\mathrm{c} \diamond}\end{array}$ & $\begin{array}{l}29.0 \pm 4.0^{\mathrm{a} \#} \\
30.1 \pm 3.7^{\mathrm{a} \#} \\
27.0 \pm 3.1^{\mathrm{b} \#}\end{array}$ & $\begin{array}{l}31.2 \pm 3.2^{\mathrm{a} \#} \\
28.1 \pm 3.6^{\mathrm{b} \#} \\
26.2 \pm 3.4^{\mathrm{c} \#}\end{array}$ & \\
\hline \multirow[t]{2}{*}{$P_{\text {mean }}(\mathrm{kPa})$} & Walk & $\begin{array}{l}S_{\text {Dres }} \\
S_{\text {Icel }} \\
S_{\text {Cush }}\end{array}$ & $\begin{array}{l}7.6 \pm 0.3^{\mathrm{ab} \diamond} \\
7.2 \pm 0.4^{\mathrm{b} \diamond} \\
7.9 \pm 0.6^{\mathrm{a} \diamond}\end{array}$ & $\begin{array}{l}7.5 \pm 0.6^{\mathrm{a} \diamond} \\
7.2 \pm 0.6^{\mathrm{a} \diamond} \\
6.7 \pm 0.5^{\mathrm{b} \#}\end{array}$ & $\begin{array}{l}8.1 \pm 0.6^{\mathrm{a} \#} \\
7.7 \pm 0.6^{\mathrm{b \#}} \\
6.7 \pm 0.6^{\mathrm{c \#}}\end{array}$ & $\begin{array}{l}7.7 \pm 0.3^{\mathrm{a}} \\
7.4 \pm 0.2^{\mathrm{b}} \\
7.2 \pm 0.3^{\mathrm{b}}\end{array}$ \\
\hline & Tölt & $\begin{array}{l}S_{\text {Dres }} \\
S_{\text {Icel }} \\
S_{\text {Cush }}\end{array}$ & $\begin{array}{l}8.4 \pm 0.6^{\mathrm{a} \diamond} \\
8.5 \pm 0.6^{\mathrm{a} \diamond} \\
8.8 \pm 0.8^{\mathrm{a} \diamond}\end{array}$ & $\begin{array}{l}8.9 \pm 0.8^{\mathrm{a} \diamond \#} \\
9.1 \pm 0.9^{\mathrm{a} \diamond} \\
7.8 \pm 0.5^{\mathrm{b} \#}\end{array}$ & $\begin{array}{l}9.2 \pm 0.7^{\mathrm{a} \#} \\
8.7 \pm 0.6^{\mathrm{b} \diamond} \\
7.2 \pm 0.8^{\mathrm{c} \dagger}\end{array}$ & $\begin{array}{l}8.8 \pm 0.4^{\mathrm{a}} \\
8.8 \pm 0.3^{\mathrm{a}} \\
8.1 \pm 0.6^{\mathrm{b}}\end{array}$ \\
\hline \multirow[t]{2}{*}{$P_{\max }(\mathrm{kPa})$} & Walk & $\begin{array}{l}S_{\text {Dres }} \\
S_{\text {Icel }} \\
S_{\text {Cush }}\end{array}$ & $\begin{array}{l}8.6 \pm 0.4^{\mathrm{a} \diamond} \\
7.9 \pm 0.5^{\mathrm{b} \diamond} \\
8.6 \pm 0.7^{\mathrm{a} \diamond}\end{array}$ & $\begin{array}{l}8.3 \pm 0.8^{\mathrm{a} \diamond} \\
8.1 \pm 0.8^{\mathrm{a} \diamond} \\
7.6 \pm 0.5^{\mathrm{b} \#}\end{array}$ & $\begin{array}{l}9.5 \pm 0.7^{\mathrm{a} \#} \\
9.0 \pm 0.7^{\mathrm{b \#}} \\
7.8 \pm 0.8^{\mathrm{c \#}}\end{array}$ & $\begin{array}{l}8.5 \pm 0.4^{\mathrm{a}} \\
8.1 \pm 0.4^{\mathrm{b}} \\
7.9 \pm 0.4^{\mathrm{b}}\end{array}$ \\
\hline & Tölt & $\begin{array}{l}S_{\text {Dres }} \\
S_{\text {Icel }} \\
S_{\text {Cush }}\end{array}$ & $\begin{array}{l}10.8 \pm 1.2^{\mathrm{a} \diamond} \\
10.2 \pm 0.9^{\mathrm{a} \diamond} \\
10.3 \pm 1.1^{\mathrm{a} \diamond}\end{array}$ & $\begin{array}{l}12.5 \pm 1.2^{\mathrm{a} \#} \\
12.2 \pm 1.2^{\mathrm{a} \#} \\
10.5 \pm 0.8^{\mathrm{b} \diamond}\end{array}$ & $\begin{array}{r}12.6 \pm 1.4^{\mathrm{a} \#} \\
11.6 \pm 1.2^{\mathrm{b} \#} \\
9.2 \pm 1.2^{\mathrm{c} \#}\end{array}$ & $\begin{array}{l}11.7 \pm 1.0^{\mathrm{a}} \\
11.0 \pm 0.6^{\mathrm{b}} \\
10.0 \pm 0.8^{\mathrm{c}}\end{array}$ \\
\hline \multirow[t]{2}{*}{$P_{\text {peak }}(\mathrm{kPa})$} & Walk & $\begin{array}{l}S_{\text {Dres }} \\
S_{\text {Icel }} \\
S_{\text {Cush }}\end{array}$ & $\begin{array}{l}16.9 \pm 1.1^{\mathrm{a} \diamond} \\
22.0 \pm 3.2^{\mathrm{b} \diamond} \\
20.2 \pm 2.4^{\mathrm{c} \diamond}\end{array}$ & $\begin{array}{l}14.6 \pm 1.9^{\mathrm{a} \#} \\
14.6 \pm 1.1^{\mathrm{a} \#} \\
12.5 \pm 1.0^{\mathrm{b} \#}\end{array}$ & $\begin{array}{l}17.4 \pm 2.3^{\mathrm{a} \diamond} \\
20.3 \pm 1.9^{\mathrm{b} \dagger} \\
14.6 \pm 2.0^{\mathrm{c} \dagger}\end{array}$ & \\
\hline & Tölt & $\begin{array}{l}S_{\text {Dres }} \\
S_{\text {Icel }} \\
S_{\text {Cush }}\end{array}$ & $\begin{array}{l}27.2 \pm 4.7^{\mathrm{a} \diamond} \\
30.2 \pm 3.3^{\mathrm{b} \diamond} \\
28.0 \pm 4.4^{\mathrm{ab} \diamond}\end{array}$ & $\begin{array}{l}20.5 \pm 1.6^{\mathrm{a} \#} \\
22.7 \pm 2.4^{\mathrm{b} \#} \\
16.8 \pm 2.1^{\mathrm{c \#}}\end{array}$ & $\begin{array}{l}20.6 \pm 2.4^{\mathrm{a} \#} \\
21.2 \pm 2.1^{\mathrm{a} \#} \\
15.4 \pm 2.8^{\mathrm{b} \#}\end{array}$ & \\
\hline
\end{tabular}

Total loaded area was split into equal transverse thirds (TD): $\mathrm{TD}_{\text {front }}, \mathrm{TD}_{\text {mid }}$ and $\mathrm{TD}_{\text {hind, }}$, front, middle and hind thirds, respectively. All data were derived from an averaged, time-standardised stride.

a,b,c Significant $(P<0.05)$ differences between the saddles for each third or total value and gait are indicated with different superscripts.

$\diamond, \#, \uparrow$ Significant differences within each saddle between front, middle and hind thirds are indicated with different superscripts. 
Table 2

Group means ( \pm standard deviations) of temporal, spatial and kinematic variables, including centre of pressure (COP) data, of 12 Icelandic horses ridden with three different saddles ( $S_{\text {Dres }}$, dressage-style saddle; $S_{\text {Icel, }}$ Icelandic saddle; $S_{\text {Cush, }}$, treeless saddle cushion) at walk (mean \pm standard deviation $1.33 \pm 0.01 \mathrm{~m} / \mathrm{s}$ ).

\begin{tabular}{|c|c|c|c|c|c|}
\hline Variables & & Units & $S_{\text {Dres }}$ & $S_{\text {Icel }}$ & $S_{\text {Cush }}$ \\
\hline SD & & s & $1.021 \pm 0.054$ & $1.023 \pm 0.049$ & $1.030 \pm 0.043$ \\
\hline StD forelimb & & $\% \mathrm{SD}$ & $65.2 \pm 1.1$ & $65.2 \pm 1.2$ & $65.2 \pm 0.9$ \\
\hline StD hind limb & & $\%$ SD & $66.6 \pm 1.7$ & $66.5 \pm 1.8$ & $66.8 \pm 1.6$ \\
\hline $\mathrm{StpD}_{\text {lat }}$ & & $\%$ SD & $24.6 \pm 3.5$ & $24.6 \pm 3.6$ & $25.0 \pm 3.4$ \\
\hline StL forelimb & & $\mathrm{m}$ & $0.88 \pm 0.06$ & $0.88 \pm 0.05$ & $0.89 \pm 0.05$ \\
\hline StL hind limb & & $\mathrm{m}$ & $0.87 \pm 0.04$ & $0.88 \pm 0.03$ & $0.88 \pm 0.03$ \\
\hline OR & & $\mathrm{m}$ & $-0.06 \pm 0.08$ & $-0.05 \pm 0.09$ & $-0.06 \pm 0.08$ \\
\hline $\mathrm{Fz}_{\text {peak }}$ forelimb & & $\mathrm{N} / \mathrm{kg}$ & $6.46 \pm 0.31^{\mathrm{a}}$ & $6.37 \pm 0.26^{\mathrm{b}}$ & $6.35 \pm 0.30^{b}$ \\
\hline $\mathrm{Fz}_{\mathrm{P} 1}$ hind limb & & $\mathrm{N} / \mathrm{kg}$ & $4.08 \pm 0.15$ & $4.09 \pm 0.18$ & $4.11 \pm 0.20$ \\
\hline $\mathrm{Fz}_{\mathrm{P} 2}$ hind limb & & $\mathrm{N} / \mathrm{kg}$ & $3.79 \pm 0.20$ & $3.78 \pm 0.17$ & $3.77 \pm 0.17$ \\
\hline Iz forelimb & & $\mathrm{Ns} / \mathrm{kg}$ & $2.99 \pm 0.19$ & $2.99 \pm 0.19$ & $2.99 \pm 0.16$ \\
\hline Iz hind limb & & $\mathrm{Ns} / \mathrm{kg}$ & $2.02 \pm 0.09^{\mathrm{a}}$ & $2.03 \pm 0.08^{a}$ & $2.06 \pm 0.08^{b}$ \\
\hline $\mathrm{Iz}_{\text {fore }}$ (unit: \%) & & $\%$ & $59.7 \pm 1.1^{\mathrm{a}}$ & $59.5 \pm 1.3^{\mathrm{ab}}$ & $59.2 \pm 1.2^{\mathrm{b}}$ \\
\hline Protraction angle forelimb & Maximum & $\circ$ & $18.7 \pm 2.6$ & $18.8 \pm 2.4$ & $18.9 \pm 2.2$ \\
\hline Retraction angle forelimb & Maximum & $\circ$ & $-30.2 \pm 1.9$ & $-30.2 \pm 1.7$ & $-30.5 \pm 1.7$ \\
\hline Protraction angle hind limb & Maximum & $\circ$ & $22.8 \pm 1.6$ & $22.9 \pm 1.5$ & $23 \pm 1.5$ \\
\hline Retraction angle hind limb & Maximum & $\circ$ & $-16.7 \pm 1.4$ & $-16.8 \pm 1.2$ & $-17 \pm 1.3$ \\
\hline Forearm angle & Maximum & $\circ$ & $43.7 \pm 3.6$ & $43.5 \pm 3.5$ & $43.9 \pm 3.4$ \\
\hline Shoulder $z$-rotation & ROM & $\circ$ & $21.5 \pm 3.1^{\mathrm{a}}$ & $21.3 \pm 3.4^{\mathrm{a}}$ & $22.1 \pm 2.9^{\mathrm{b}}$ \\
\hline Shoulder $x$-rotation & ROM & $\circ$ & $12.5 \pm 2$ & $12.4 \pm 1.6$ & $12.7 \pm 1.5$ \\
\hline Head height & $z$-Mean & $\mathrm{mm}$ & $1390 \pm 58$ & $1386 \pm 46$ & $1386 \pm 55$ \\
\hline \multirow[t]{2}{*}{ Rider position } & $x$-Mean & $\mathrm{mm}$ & $234 \pm 35^{\mathrm{a}}$ & $222 \pm 31^{\mathrm{b}}$ & $208 \pm 30^{c}$ \\
\hline & $x$-ROM & $\mathrm{mm}$ & $44 \pm 8^{\mathrm{a}}$ & $40 \pm 6^{\mathrm{b}}$ & $37 \pm 7^{b}$ \\
\hline Rider back angle & $x$-ROM & $\circ$ & $5.7 \pm 1.4$ & $5.1 \pm 1.7$ & $5.0 \pm 1.4$ \\
\hline COP position & $x$-Mean & $\mathrm{mm}$ & $446 \pm 36^{a}$ & $445 \pm 30^{\mathrm{a}}$ & $426 \pm 30^{\mathrm{b}}$ \\
\hline \multirow[t]{2}{*}{ COP } & $x$-ROM & $\mathrm{mm}$ & $45 \pm 8^{\mathrm{a}}$ & $40 \pm 8^{\mathrm{b}}$ & $30 \pm 8^{c}$ \\
\hline & $y$-ROM & $\mathrm{mm}$ & $26 \pm 5^{a}$ & $24 \pm 4^{\mathrm{ab}}$ & $21 \pm 3^{b}$ \\
\hline Caudal edge loaded area & $x$-Mean & $\mathrm{mm}$ & $207 \pm 39^{a}$ & $186 \pm 32^{b}$ & $128 \pm 39^{c}$ \\
\hline Length loaded area & $x$-Mean & $\mathrm{mm}$ & $459 \pm 17^{\mathrm{a}}$ & $488 \pm 0^{\mathrm{b}}$ & $516 \pm 17^{c}$ \\
\hline
\end{tabular}

Kinetic variables: SD, stride duration; StD, stance duration relative to $\mathrm{SD}$; $\mathrm{StpD}_{\text {lat }}$, lateral step duration relative to SD; StL, stance length; OR, overreach distance (positive if the hind hoof strikes in front of the ipsilateral front hoof); $\mathrm{Fz}_{\mathrm{peak}}, \mathrm{Fz}_{\mathrm{P} 1}$ and $\mathrm{Fz}_{\mathrm{P} 2}$, peak vertical forces; Iz, limb impulse; Iz $\mathrm{I}_{\text {fore, }}$, percentage of total impulse carried by both forelimbs. Kinematic variables (left-handed coordinate system, $x$-axis vs. horse's head, $z$-axis upward; mean, mean value of entire stride; ROM, range of motion during stride; for the indicated dimensions): Protraction/retraction, forelimb or hind limb angles, sagittal plane, with zero reference for vertical orientation of metacarpus (markers: carpus, metacarpophalangeal joint) or metatarsus (markers: tarsus, metatarsophalangeal joint) during stance phase (positive if metacarpophalangeal joint is cranial to carpus); forearm angle, sagittal plane, with reference to a vertical to ground through elbow marker (positive if carpus is cranial to elbow); rider position, distance from rider sacrum to horse lumbar vertebra 5 (L5); rider back angle, with reference to the $z$-axis through rider's sacrum; COP position, centre of pressure (COP) position relative to horse's L5, as calculated distance of COP - markers at caudal end of saddle mat - L5; COP $x$-ROM, $y$-ROM, range of motion of COP; caudal edge of loaded area, distance from most distal loaded sensor row - horse L5; length of loaded area, longitudinal extent of loaded sensor rows.

All data were derived from an averaged, time-standardised stride.

a,b,c Significant differences $(P<0.05)$ between saddles are indicated with different superscripts.

with the rider position, it was located furthest caudally with $S_{\text {Cush }}$ ( -20 to $-26 \mathrm{~mm})$.

Both riders mentioned that more effort was required to maintain their stability with $S_{\text {Cush }}$ compared to the saddles with trees, predominantly at the tölt. However, longitudinal ROM of COP was smallest in $S_{\text {Cush }}$ (Tables 2 and 3).

\section{Influence of saddles on horse kinetics and kinematics}

Compared to $S_{\text {Dres }}$ there was an impulse shift of $0.5 \%$ toward the hindquarters with $S_{\text {Cush }}$, but there was no significant difference between $S_{\text {Dres }}$ and $S_{\text {Icel }}$ at either gait. Forelimb action, protraction and retraction angles of the limbs, and temporal and spatial variables did not differ between the saddles. At walk, shoulder $z$-rotation was more pronounced in $S_{\text {Cush }}$ and forelimb forces had a single peak $\left(\mathrm{Fz}_{\text {peak }}\right)$, whereas hind limbs showed typical double peaks $\left(\mathrm{Fz}_{\mathrm{P} 1}, \mathrm{Fz}_{\mathrm{P} 2}\right)$ with all saddles. Concomitant to the above mentioned impulse shift cranially in $S_{\text {Dres }}$, a small but significant increase in forelimb $\mathrm{Fz}_{\text {peak }}$ was observed at walk.

\section{Discussion}

This study compared three saddle types currently used in Icelandic horses with regard to the saddle pressure patterns, their influence on the horses' locomotion and rider stability. The highest peak pressures $\left(P_{\text {peak }}\right)$ occurred in all saddle types predominantly in $\mathrm{TD}_{\text {front }}$. Due to the basically different design of the treeless saddle $\left(S_{\text {Cush }}\right)$ and the saddles with trees, the exact position of $P_{\text {peak }}$ within $\mathrm{TD}_{\text {front }}$ differed (Fig. 2). With $S_{\text {Cush }}, P_{\text {peak }}$ was localised adjacent to the spinous processes, especially in horses with more pronounced withers, for which the saddle had no wither clearance. In horses with extremely short backs, the same phenomenon occurred to a lesser extent at the rear end of the saddle.

Unfortunately, the pressures directly over the spinous processes could not be measured, because the standard placement of the pressure sensitive mat always left a small gap along the spine. In the saddles with trees, the high pressure areas were located more laterally, caused by the head plates being slightly too wide for all horses with the $S_{\text {Icel }}$ and in some of the horses with the $S_{\text {Dres. }}$. Besides the bridging phenomenon, badly fitting head plates are a problem often seen in our clinical cases and also pointed out by Harman (1995). Even with the availability of four head plates of different sizes in the $S_{\text {Dres, }}$, it was not possible to find a perfect fit for all horses. This emphasises that, even if the majority of horses of the same breed have a similar back shape, the saddle still needs to be fitted individually (Harman, 2004).

$S_{\text {Cush }}$ was most loaded in $\mathrm{TD}_{\text {front }}$ and showed (compared to the saddles with trees) a reduced force distribution to the caudal thirds, although riders were sitting in the middle of the saddle. A similar force distribution was observed in a treeless racing saddle when galloping in a racing seat (Latif et al., 2010); however, this 
Table 3

Group means ( \pm standard deviations) of temporal, spatial and kinematic variables, including centre of pressure (COP) data, of 12 Icelandic horses ridden with three different saddles $\left(S_{\text {Dres }}\right.$, dressage-style saddle; $S_{\text {Icel }}$, Icelandic saddle; $S_{\text {Cush }}$, treeless saddle cushion) at tölt (mean \pm standard deviation $3.43 \pm 0.03 \mathrm{~m} / \mathrm{s}$ ).

\begin{tabular}{|c|c|c|c|c|c|}
\hline Variables & & Units & $S_{\text {Dres }}$ & $S_{\text {Icel }}$ & $S_{\text {Cush }}$ \\
\hline SD & & $\mathrm{s}$ & $0.548 \pm 0.024$ & $0.548 \pm 0.024$ & $0.547 \pm 0.023$ \\
\hline StD forelimb & & $\%$ SD & $47.2 \pm 2.9$ & $46.9 \pm 2.7$ & $47.2 \pm 2.8$ \\
\hline StD hind limb & & $\%$ SD & $51.5 \pm 1.5^{\mathrm{a}}$ & $51.8 \pm 1.8^{\mathrm{ab}}$ & $52.1 \pm 1.7^{\mathrm{b}}$ \\
\hline StpD lat & & $\%$ SD & $17.8 \pm 2.2$ & $18.0 \pm 2.7$ & $18.0 \pm 2.4$ \\
\hline StL forelimb & & $\mathrm{m}$ & $0.90 \pm 0.05$ & $0.89 \pm 0.05$ & $0.89 \pm 0.05$ \\
\hline StL hind limb & & $\mathrm{m}$ & $0.93 \pm 0.04$ & $0.93 \pm 0.04$ & $0.93 \pm 0.03$ \\
\hline OR & & $\mathrm{m}$ & $0.55 \pm 0.11$ & $0.54 \pm 0.11$ & $0.53 \pm 0.12$ \\
\hline $\mathrm{Fz}_{\text {peak }}$ forelimb & & $\mathrm{N} / \mathrm{kg}$ & $9.56 \pm 0.61$ & $9.57 \pm 0.54$ & $9.49 \pm 0.52$ \\
\hline $\mathrm{Fz}_{\text {peak }}$ hind limb & & $\mathrm{N} / \mathrm{kg}$ & $6.57 \pm 0.31$ & $6.59 \pm 0.31$ & $6.57 \pm 0.30$ \\
\hline Iz forelimb & & $\mathrm{Ns} / \mathrm{kg}$ & $1.54 \pm 0.07^{\mathrm{a}}$ & $1.53 \pm 0.07^{\mathrm{ab}}$ & $1.53 \pm 0.06^{\mathrm{b}}$ \\
\hline Iz hind limb & & $\mathrm{Ns} / \mathrm{kg}$ & $1.15 \pm 0.07$ & $1.16 \pm 0.06$ & $1.16 \pm 0.06$ \\
\hline $\mathrm{I} \mathrm{z}_{\text {fore }}$ (unit: \%) & & $\%$ & $57.4 \pm 1.1^{\mathrm{a}}$ & $57.0 \pm 1.2^{\mathrm{ab}}$ & $56.9 \pm 1.0^{\mathrm{b}}$ \\
\hline Protraction angle forelimb & Maximum & $\circ$ & $23.7 \pm 2.6$ & $23.6 \pm 2.7$ & $23.3 \pm 2.6$ \\
\hline Retraction angle forelimb & Maximum & $\circ$ & $-28 \pm 2.4$ & $-27.7 \pm 2.7$ & $-27.9 \pm 2.1$ \\
\hline Protraction angle hind limb & Maximum & $\circ$ & $26.1 \pm 2.2$ & $26.1 \pm 2.1$ & $26 \pm 2.2$ \\
\hline Retraction angle hind limb & Maximum & $\circ$ & $-15.2 \pm 1.5$ & $-15.2 \pm 1.7$ & $-15.2 \pm 1.6$ \\
\hline Forearm angle & Maximum & $\circ$ & $65.6 \pm 7.2$ & $65.1 \pm 7.2$ & $65.4 \pm 6.8$ \\
\hline Shoulder $z$-rotation & ROM & $\circ$ & $17.6 \pm 3.1$ & $17.4 \pm 3$ & $17.5 \pm 3.2$ \\
\hline Shoulder $x$-rotation & ROM & $\circ$ & $9.7 \pm 2.1$ & $9.9 \pm 2.1$ & $9.8 \pm 2.3$ \\
\hline Head height & $z$-Mean & $\mathrm{mm}$ & $1536 \pm 55$ & $1536 \pm 59$ & $1538 \pm 60$ \\
\hline \multirow[t]{2}{*}{ Rider position } & $x$-Mean & $\mathrm{mm}$ & $250 \pm 48^{\mathrm{a}}$ & $235 \pm 44^{\mathrm{b}}$ & $220 \pm 51^{\mathrm{c}}$ \\
\hline & $x$-ROM & $\mathrm{mm}$ & $45 \pm 11$ & $46 \pm 11$ & $46 \pm 12$ \\
\hline Rider back angle & $x$-ROM & $\circ$ & $6.0 \pm 1.5$ & $5.9 \pm 1.6$ & $6.1 \pm 1.5$ \\
\hline COP position & $x$-Mean & $\mathrm{mm}$ & $485 \pm 44^{\mathrm{a}}$ & $487 \pm 35^{\mathrm{a}}$ & $461 \pm 41^{\mathrm{b}}$ \\
\hline \multirow[t]{2}{*}{ COP } & $x$-ROM & $\mathrm{mm}$ & $36 \pm 12^{a}$ & $40 \pm 11^{\mathrm{a}}$ & $28 \pm 10^{\mathrm{b}}$ \\
\hline & $y$-ROM & $\mathrm{mm}$ & $16 \pm 4$ & $15 \pm 3$ & $16 \pm 4$ \\
\hline Caudal edge loaded area & $x$-Mean & $\mathrm{mm}$ & $250 \pm 53^{a}$ & $224 \pm 42^{\mathrm{b}}$ & $171 \pm 44^{\mathrm{c}}$ \\
\hline Length loaded area & $x$-Mean & $\mathrm{mm}$ & $450 \pm 16^{\mathrm{a}}$ & $488 \pm 23^{b}$ & $500 \pm 18^{\mathrm{b}}$ \\
\hline
\end{tabular}

Kinetic variables: SD, stride duration; StD, stance duration relative to SD; $S_{\text {lpD }}$, lateral step duration relative to SD; StL, stance length; OR, overreach distance (positive if the hind hoof strikes in front of the ipsilateral front hoof); $\mathrm{Fz}_{\mathrm{peak}}, \mathrm{Fz}_{\mathrm{P} 1}$ and $\mathrm{Fz}_{\mathrm{P} 2}$, peak vertical forces; Iz, limb impulse; Iz $\mathrm{z}_{\text {fore, }}$, percentage of total impulse carried by both forelimbs. Kinematic variables (left-handed coordinate system, $x$-axis vs. horse's head, $z$-axis upward; mean, mean value of entire stride; ROM, range of motion during stride; for the indicated dimensions): Protraction/retraction, forelimb or hind limb angles, sagittal plane, with zero reference for vertical orientation of metacarpus (markers: carpus, metacarpophalangeal joint) or metatarsus (markers: tarsus, metatarsophalangeal joint) during stance phase (positive if metacarpophalangeal joint is cranial to carpus); forearm angle, sagittal plane, with reference to a vertical to ground through elbow marker (positive if carpus is cranial to elbow); rider position, distance from rider sacrum to horse lumbar vertebra 5 (L5); rider back angle, with reference to the $z$-axis through rider's sacrum; COP position, centre of pressure (COP) position relative to horse's L5, as calculated distance of COP - markers at caudal end of saddle mat - L5; COP $x$-ROM, $y$-ROM, range of motion of COP; caudal edge of loaded area, distance from most distal loaded sensor row - horse L5; length of loaded area, longitudinal extent of loaded sensor rows. All data were derived from an averaged, time-standardised stride.

a,b,c Significant differences $(P<0.05)$ between saddles are indicated with different superscripts.

corresponded to the rider's centre of mass. Similarly, with a treeless dressage saddle investigated at sitting trot, most force was concentrated below the rider's COM in the middle third (Belock et al., 2012). These findings are therefore in contrast to our observations that the maximal loaded part was clearly cranial to the rider's centre of mass. There is a great variety of treeless saddles available on the market, making comparisons difficult. The treeless saddle used in this study was new and, therefore, still very rigid, straight and disproportionally long compared to the short backs of the study horses.

The studies cited above were conducted on Arabians and English Thoroughbred racehorses at trot. Since the tölt normally has no suspension phase (Feldmann, 1986) and accounts only for $25 \%$ of the vertical excursion of the COM $(12 \mathrm{~mm}$; Biknevicius et al. 2006) in Warmblood horses at trot $(3.9 \mathrm{~m} / \mathrm{s}, 53 \mathrm{~mm}$; Buchner et al., 2000), $S_{\text {Cush }}$ might have been rigid enough to distribute the rider's weight to the front and hind thirds.

For all saddles, mean and peak pressures were below critical values reported to induce clinical signs of saddle soreness at the withers (von Peinen et al., 2010). Nyikos et al. (2005) ascertained that pressure tolerance is lower in the lumbar region compared to the withers. However, the threshold pressures reported to be associated with pain were not reached in any of the saddles in this study.

In English riding, it is undesirable to have a saddle reaching into the lumbar region. Icelandic horses often have short backs and are ridden by adults who need a large seat to ride comfortably. How a horse's back movement and health are influenced by the distance to which a saddle reaches into the lumbar region remains to be investigated.

According to manuals regarding the riding technique of Icelandic horses, the rider needs to induce a slight weight shift toward the hindquarters in order to support the horse at the tölt. Kinetic measurements in the present study demonstrated that forelimbhind limb balance was influenced by different rider positions relative to the horse's back. The riders were positioned furthest back in $S_{\text {Cush }}$, which was probably due to the saddle being longer than the saddles with trees. The head-neck position (HNP) can be excluded as the cause of the impulse shift, since horses were ridden with the same head-neck elevation with all three saddles.

At the tölt, longitudinal $(x-)$ ROM of COP was smaller in $S_{\text {Cush }}$ than in the saddles with trees, although riders subjectively reported needing more effort to maintain stability. Since the riders' longitudinal $(x$-)ROM was the same for all saddles, the lower $x$ ROM of COP in the $S_{\text {Cush }}$ could be explained by a less effective transfer of rider movement to the back than in the saddles with trees.

A clear four-beat rhythm of the tölt is a prerequisite for Icelandic horses when competing. Zips et al. (2001) stated that only a few horses show a true tölt pattern. In this study, horses showed a tölt with lateral couplets ( $\mathrm{StpD}_{\text {lat }}$ around $18 \%$ of $\left.\mathrm{SD}\right)$ and this rhythm was not influenced by the different saddles. Also, the desirable high forelimb action was similar for all saddles, probably due to horses having nearly the same high head-neck elevation. Interestingly, 

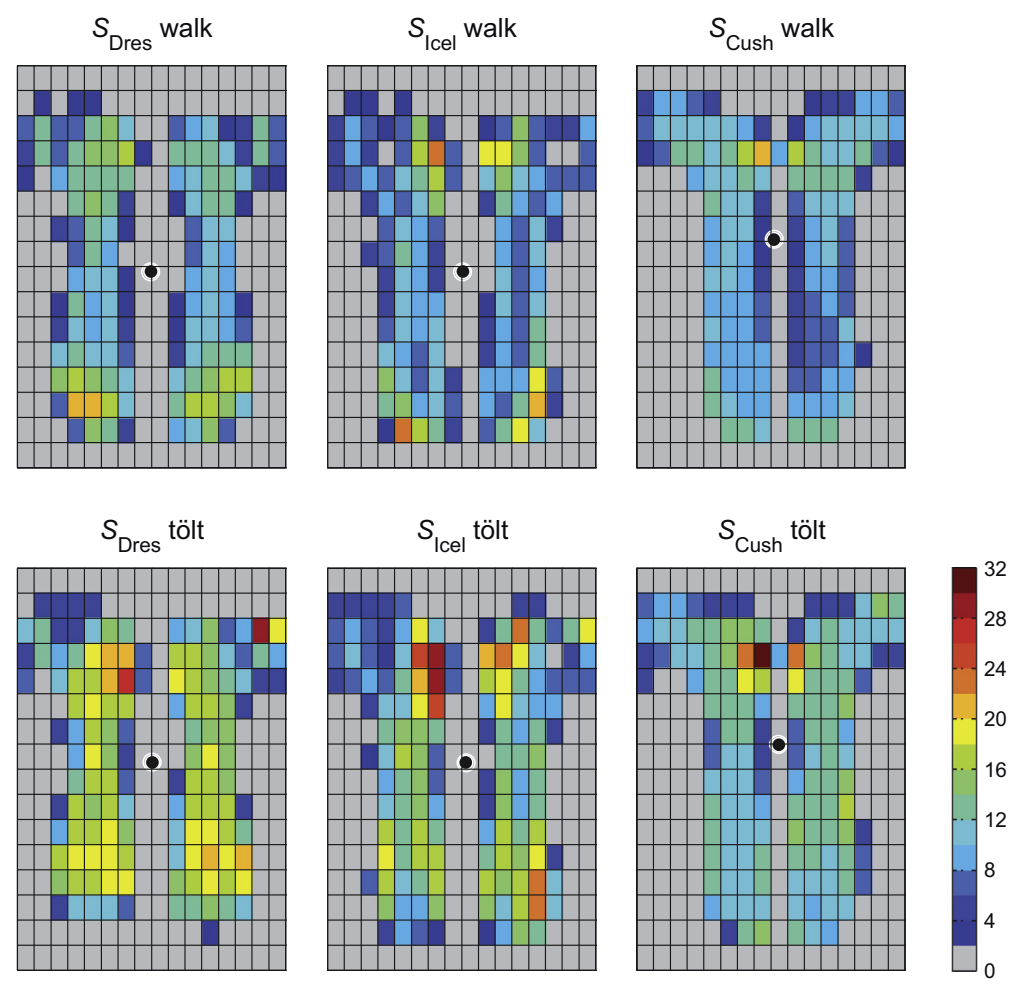

Fig. 2. Maximum pressure pictures (MPP) for the three saddles ( $S_{\text {Dres }}$, dressage saddle; $S_{\text {Icel, }}$ Icelandic saddle; $S_{\text {Cush }}$, saddle cushion) at the walk (top line) and tölt (bottom) for one representative horse. The MPP depicts the peak pressure $\left(P_{\text {peak }}, \mathrm{kPa}\right)$ observed during the standardised, averaged stride for each sensor cell. Superimposed is the COP stride mean position (black dot).

the larger shoulder $z$-rotation with $S_{\text {Cush }}$, likely due to the lack of a head plate, did not lead to higher forelimb action.

With all saddles, when comparing tölt to walk, an impulse shift of approximately $2.3 \%$ to the hindquarters was observed at tölt, although the rider and the COP were more cranially positioned in relation to the horse. This may be explained by a higher HNP at the tölt. Former studies with dressage horses showed that elevating the head and neck both in the ridden (Weishaupt et al., 2006) and unridden situations (Waldern et al., 2009) shifted weight to the hindquarters.

At walk, a distinct bridging characteristic was observed for $S_{\text {Dres }}$ and, to a slightly lesser extent, $S_{\text {Icel }}$; it diminished at tölt. von Peinen et al. (2006) found that a low (compared to high) HNP redistributed the forces to the centre of the saddle contact area due to a rising of the back. In the present study, a similar phenomenon with respect to force distribution was observed when comparing tölt to walk, despite the high HNP at the tölt. A higher tension and active stabilisation of the trunk to allow the high stride frequency and/or to compensate for the more dynamic vertical movement of the rider at tölt could explain this phenomenon.

\section{Conclusions}

The three saddles used in this study exhibited different pressure patterns but, contrary to our hypothesis, the back was not loaded more caudally in $S_{\text {lcel }}$ compared to $S_{\text {Dres. }}$. In accord with the rider position relative to the horse's back, forelimb-hind limb balance, but not limb movements or forces, was influenced by saddle type. Further investigation is necessary to determine whether these changes can be induced by placing the saddles more caudally, as practised in traditional Icelandic horse riding, above all for the tölt.

\section{Conflict of interest statement}

None of the authors has any financial or personal relationships that could inappropriately influence or bias the content of the paper.

\section{Acknowledgements}

This study was supported by the Stiftung Forschung für das Pferd, the Stiftung Temperatio and the Islandpferde-Vereinigung Schweiz. The authors wish to thank all the owners, the riders and the judge for their committed co-operation and James Jones and Isabel Imboden for assistance with revising the manuscript.

\section{References}

Belock, B., Kaiser, L.J., Lavagnino, M., Clayton, H.M., 2012. Comparison of pressure distribution under a conventional saddle and a treeless saddle at sitting trot. The Veterinary Journal 193, 87-91.

Biknevicius, A.R., Mullineaux, D.R., Clayton, H.M., 2006. Locomotor mechanics of the tölt in Icelandic horses. American Journal of Veterinary Research 67, 15051510 .

Buchner, H.H., Obermuller, S., Scheidl, M., 2000. Body centre of mass movement in the sound horse. The Veterinary Journal 160, 225-234.

Edwards, E.H., 1963. Saddlery - The Complete Guide. J.A. Allen \& Co., London, UK, pp. $181-182$.

Feldmann, A., 1986. Islandpferde Reitlehre. Thenee Druck AG, Bonn, Germany, pp. 265-268.

Haag, T., Schwörer-Haag, A., 2003. Islandpferde besser reiten. Franckh-Kosmos Verlags-GmbH \& Co., Stuttgart, Germany, pp. 102-108.

Harman, J., 1995. Practical use of a computerized saddle pressure measuring device to determine the effects of saddle pads on the horses back. Journal of Equine Veterinary Science 14, 606-611.

Harman, J., 2004. The Horse's Pain-Free Back and Saddle Fit Book. Trafalgar Square Publishing, North Pomfret, Vermont, USA, pp. 51-82. 
Latif, S.N., von Peinen, K., Wiestner, T., Bitschnau, C., Renk, B., Weishaupt, M.A. 2010. Saddle pressure patterns of three different training saddles (normal tree, flexible tree, treeless) in Thoroughbred racehorses at trot and gallop. Equine Veterinary Journal 42, 630-636.

Nyikos, S., Werner, D., Müller, J.A., Buess, C., Keel, R., Kalpen, A., Vontobel, H.D., von Plocki, K.A., Auer, J.A., von Rechenberg, B., 2005. Elektronische satteldruckmessungen im zusammenhang mit rückenproblemen bei pferden. Pferdeheilkunde 21, 187-198.

von Peinen, K., Wiestner, T., Keel, R., Roepstorff, L., Meyer, H., van Weeren, R, Weishaupt, M.A., 2006. Saddle force measurements in relation to ground reaction forces in different head neck positions in the ridden horse. In: Proceedings of the 7th International Conference of Equine Exercise Physiology (ICEEP), Fontainebleau, France, 26-31 August 2006. ICEEP Publications, Davis, California, USA, p. 124.

von Peinen, K., Wiestner, T., von Rechenberg, B., Weishaupt, M.A., 2010. Relationship between saddle pressure measurements and clinical signs of saddle soreness at the withers. Equine Veterinary Journal 42, 650-653.
Waldern, N.M., Wiestner, T., von Peinen, K., Gomez Alvarez, C.G., Roepstorff, L, Johnston, C., Meyer, H., Weishaupt, M.A., 2009. Influence of different head-neck positions on vertical ground reaction forces, linear and time parameters in the unridden horse walking and trotting on a treadmill. Equine Veterinary Journal 41, 268-273.

Weishaupt, M.A., Hogg, H.P., Wiestner, T., Denoth, J., Stussi, E., Auer, J.A., 2002. Instrumented treadmill for measuring vertical ground reaction forces in horses. American Journal of Veterinary Research 63, 520-527.

Weishaupt, M.A., Wiestner, T., von Peinen, K., Waldern, N., Roepstorff, L., van Weeren, R., Meyer, H., Johnston, C., 2006. Effect of head and neck position on vertical ground reaction forces and interlimb coordination in the dressage horse ridden at walk and trot on a treadmill. Equine Veterinary Journal Suppl. 36, 387-392.

Zips, S., Peham, C., Scheidl, M., Licka, T., Girtler, D., 2001. Motion pattern of the toelt of Icelandic horses at different speeds. Equine Veterinary Journal Suppl. 33, 109-111. 


\section{Danksagung}

An dieser Stelle möchte ich mich ganz herzlich bei allen Personen bedanken, die in irgendeiner Form zum Gelingen dieser Arbeit beigetragen haben, insbesondere bei:

Michael A. Weishaupt, meinem Referenten, für die Betreuung meiner Arbeit.

Thomas Wiestner für seine Hilfe bei der Auswertung und Statistik und für seinen unermüdlichen Einsatz bei Fragen und Sorgen jeder Art.

Nina Waldern für die Organisation der gesamten Islandpferdestudie und die vielen wertvollen Ratschläge.

Katja Geser-von Peinen für die kompetente Hilfe in allen satteltechnischen Belangen und die moralische Unterstützung.

Den Besitzern, die uns ihre Pferde anvertrauten, unseren beiden hervorragenden Reitern Bernhard Podlech und Bea Rusterholz und unserer Richterin Margrit Rusterholz.

Sabrina und Bernhard Gilly (ChampionRider), sowie der Firma TopReiter für die Sättel.

Unserem Pflegepersonal der Pferdeklinik, besonders Belinda Elkuch und Verena Hänni, für ihre geduldige und engagierte Mithilfe.

Isabel Imboden und James Jones für das hervorragende Lektorat.

Meinen Eltern und Grosseltern, die mir das Studium ermöglicht haben und meinen Geschwistern für die aufmunternden und ermutigenden Worte.

Meinem Freund Beatus für seine unendliche Geduld und moralische Unterstützung.

Der Stiftung Forschung für das Pferd, die dieses Projekt finanziell unterstützte. Damit sei auch allen Spendern, die diese Stiftung berücksichtigen, ganz herzlich gedankt. 


\section{Curriculum Vitae}

\section{Persönliche Daten}

Name

Lea Claudia Ramseier

Geburtsdatum

11.08 .1984

Geburtsort

Liestal (BL)

Nationalität

$\mathrm{CH}$

Heimatort

Trub (BE)

\section{Ausbildung}

Schulbildung

1991-1996

Primarschule Pratteln (BL)

1996-2000

Progymnasium Pratteln (BL)

2000-2003

Gymnasium Muttenz (BL)

Dezember 2003

Matura, Schwerpunktfach Latein

Studium

2004-2009

Studium der Veterinärmedizin (Schwerpunkt Pferde) an der VetsuisseFakultät der Universität Zürich, $\mathrm{CH}$

Oktober 2009

Staatsexamen an der Vetsuisse-Fakultät der Universität Zürich, $\mathrm{CH}$

2010-2012

Anfertigung der Dissertation unter Leitung von PD Dr. Michael A. Weishaupt am Departement für Pferde der Vetsuisse-Fakultät der Universität Zürich, CH

\section{Berufliche Tätigkeit}

2010-2012

Doktorandin am Sportmedizinischen Leistungszentrum, Departement für Pferde, Vetsuisse-Fakultät der Universität Zürich, CH 